CROSS-FUNCTIONAL ISSUES IN THE IMPLEMENTATION OF RELATIONSHIP MARKETING THROUGH CUSTOMER RELATIONSHIP MANAGEMENT (CRM)

by

Lynette Ryals*

Lecturer

Cranfield Centre for Advanced

Research in Marketing

Cranfield School of Management

Cranfield University

Cranfield

Bedford

MK43 0AL

Tel: $+44(0) 1234751122$

Fax: +44 (0)1234 751806

Email:

lynette.ryals@cranfield.ac.uk

*Address for correspondence
Professor Simon Knox*

Professor of Brand Marketing

Cranfield Centre for Advanced

Research in Marketing

Cranfield School of Management

Cranfield University

Cranfield

Bedford

MK43 0AL

Tel: $+44(0) 1234751122$

Fax: +44 (0)1234 751806

Email:

s.knox@cranfield.ac.uk 


\section{Biographies}

\section{LYNETTE RYALS MA (OXON) MBA FSIP Lecturer}

Lynette began her career in the City as a fund manager and stockbroker trading UK equities, options and futures, and still lectures occasionally on finance issues. She then moved to a marketing company to work on corporate development and acquisitions, subsequently transferring into the consultancy arm of the same business group.

Lynette is a Registered Representative of the London Stock Exchange and is the only woman in the UK to have passed the Fellowship examinations of the Society of Investment Professionals.

She is co-author of "Customer Relationship Management: The Business Case" a management report in the FT Prentice Hall series, with Simon Knox and Stan Maklan.

Since 1st January 2000, Lynette has also been Director of the Executive MBA programme at Cranfield.

email: lynette.ryals@cranfield.ac.uk

\section{SIMON KNOX BSc PhD Professor of Brand Marketing}

Simon Knox is Professor of Brand Marketing at the Cranfield School of Management in the UK and is a consultant to a number of multinational companies including McDonald's, Levi Strauss, DiverseyLever, BT and the Ocean Group. Upon graduating, he followed a career in the marketing of international brands with Unilever plc in a number of senior marketing roles in both detergents and foods.

Since joining Cranfield, Simon has published over 60 papers on branding and customer purchasing styles and is a regular speaker at international conferences. He is a Director of the Cranfield Centre for Advanced Research in Marketing in the School and is currently leading a research team on Customer Relationship Management. He is the co-author of the book, "Competing on Value"

(http:/www.competingonvalue.com), published by FT Pitman Publishing in the UK, Germany and the USA, and "Creating a Company for Customers", FT Prentice-Hall, in the UK and Brazil.

email: s.knox@cranfield.ac.uk 


\title{
CROSS-FUNCTIONAL ISSUES IN THE IMPLEMENTATION OF RELATIONSHIP MARKETING THROUGH CUSTOMER RELATIONSHIP MANAGEMENT (CRM)
}

\begin{abstract}
There is a major change in the way which companies organise themselves as firms switch from product - based to customer-based structures. A key driver of this change is the advent of Customer Relationship Management which, underpinned by information systems convergence and the development of supporting software, promises significantly to improve the implementation of Relationship Marketing principles.
\end{abstract}

In this paper we explore the three main issues that can enable (or hinder) the development of Customer Relationship Management in the service sector; the organisational issues of culture and communication, management metrics and crossfunctional integration - especially between marketing and information technology.

\section{Keywords}

Customer relationship management

Cross-functional integration

Information technology

Relationship Marketing 


\section{Introduction}

Customer Relationship Management (CRM) has its roots in relationship marketing which is based in turn on the formative work by Berry (1983), the IMP Group (see e.g. Ford, 1990) and Christopher et al (1991). Seminal contributions to the relationship marketing debate were made by Reichheld and Sasser (1990) and Reichheld (1996) reporting on the customer retention work of Bain and Co. These findings indicated that a 5\% increase in customer retention resulted in an increase in average customer lifetime value of between $35 \%$ and $95 \%$, leading to significant improvements in company profitability ( see Figure 1).

Figure 1: Impact of a 5\% Increase in Retention Rate on Customer Net Present Value

\begin{tabular}{|l|c|}
\hline Industry & $\begin{array}{c}\text { \% Increase in } \\
\text { Customer NPV }\end{array}$ \\
\hline Advertising Agency & 95 \\
\hline Life Insurance & 90 \\
\hline Bank & 85 \\
\hline Insurance & 84 \\
\hline Car Service & 81 \\
\hline Credit Card & 75 \\
\hline Laundry & 45 \\
\hline Facilities Management & 40 \\
\hline Software & 35 \\
\hline
\end{tabular}

Source: adapted from Reichheld, 1996

Reichheld concluded that there are six underlying reasons why retained customers are more profitable (p. 39):

- Customer acquisition costs may be high, so customers may not become profitable unless they are retained for one or more years;

- There will be a stream of profits from the customer in each year after acquisition costs are covered; 
- Customers buy more over time, so revenues go up; Companies become more efficient at serving them (there is a learning curve to the relationship), so costs go down;

- Retained and satisfied customers may refer other potential customers;

- The relationship has a value to the customer too, so that retained customers tend to become less price-sensitive.

The purpose of relationship marketing is to improve long run profitability by shifting from transaction-based marketing, with its emphasis on winning new customers, to customer retention through effective management of customer relationships (Christopher et al., p.19, 1991). While the development of theory in relationship marketing continues unabated, the key question facing practitioners is, how can this shift in management focus be implemented in practice?

This paper sets out to address issues concerning relationship marketing implementation through the application of Customer Relationship Management $(\mathrm{CRM})$ and related technologies.

\section{Customer Relationship Management}

CRM complements the relationship marketing perspective. It is defined by Couldwell (1998) as, “. . . a combination of business process and technology that seeks to understand a company's customers from the perspective of who they are, what they do, and what they're like." As is the case with relationship marketing, CRM focuses on customer retention (Lockard, 1998; Deighton, 1998) and relationship development (Galbreath, 1998). According to Kutner and Cripps (1997), CRM is founded on four relationship-based tenets:

- Customers should be managed as important assets.

- Customer profitability varies; not all customers are equally desirable.

- Customers vary in their needs, preferences, buying behaviour and price sensitivity.

- By understanding customer drivers and customer profitability, companies can tailor their offerings to maximise the overall value of their customer portfolio. 
Anton (1996) characterises CRM as an integrated approach to managing relationships. However, critically, he underpins relationship management with "continuous improvement or re-engineering" of customer value through better service recovery and competitive positioning of the offer (see Figure 2).

Figure 2: CRM - an Integrated Approach to managing relationships

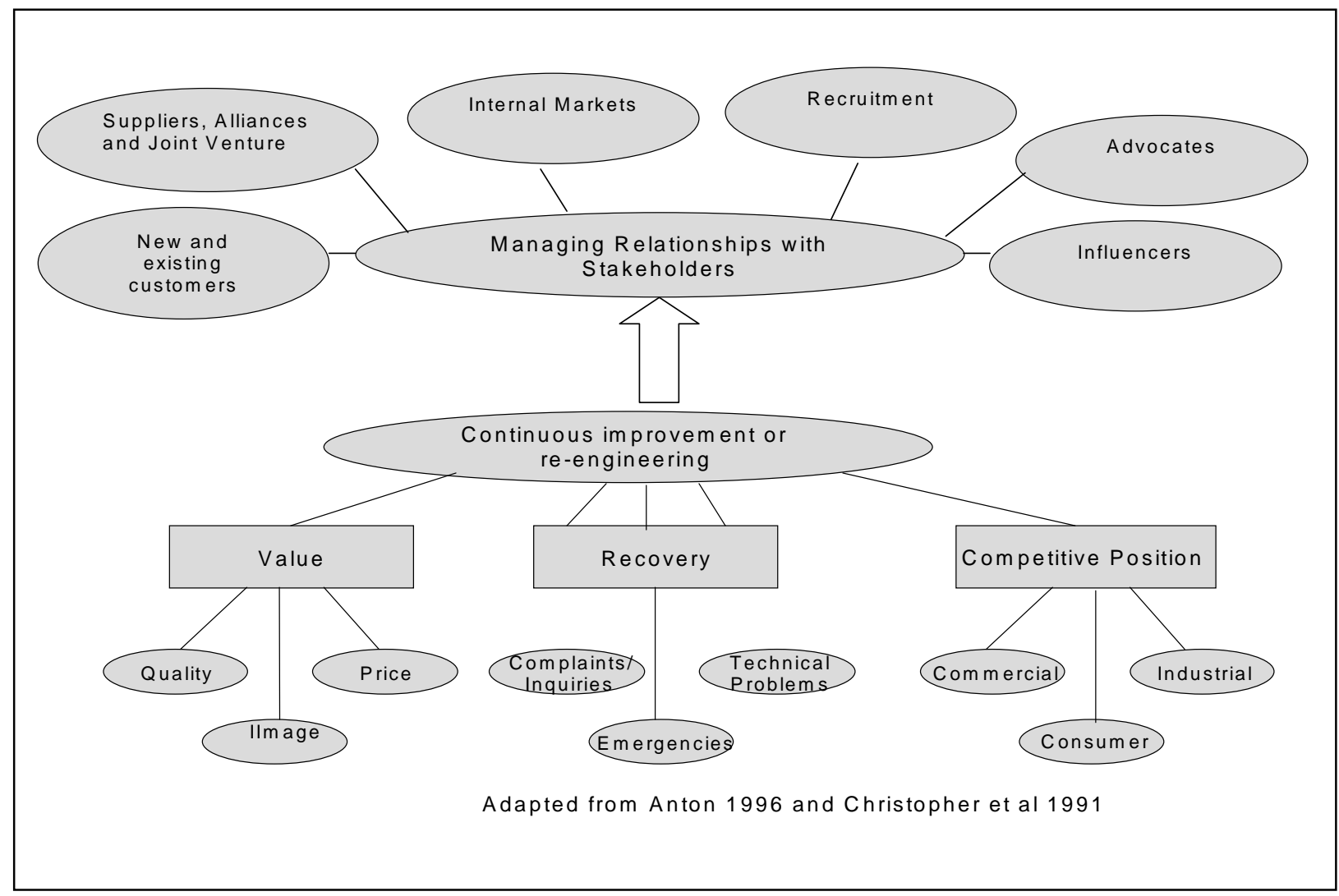

Others emphasise a technological rather than a relational perspective to CRM; Peppers and Rogers (1995) claim that, “...the marketplace of the future is undergoing a technology-driven metamorphosis.”, which Kutner and Cripps (1997) encapsulate as, "data-driven marketing".

Notwithstanding these technological perspectives, the philosophical bases of CRM are a relationship orientation, customer retention and superior customer value created through process management. IT is the 'glue' that holds these together and enables the whole to be operationalised. In consequence, the successful implementation of CRM requires Marketing and IT to work closely together to maximise the return on 
customer information. This will almost certainly require a degree of cross-functional reorganisation.

In summary, the key characteristics of CRM are:

- A customer relationship perspective aimed at the long-term retention of selected customers.

- Gathering and integrating information on customers.

- Use of dedicated software to analyse this information (often in real time).

- Segmentation by expected customer lifetime value.

- Micro-segmentation of markets according to customers' needs and wants.

- Customer value creation through process management (Hammer \& Champy, 1993; Hamel \& Prahalad, 1994).

- Customer value delivery through service tailored to micro-segments, facilitated by detailed, integrated customer profiles.

- A shift in emphasis from managing product portfolios to managing portfolios of customers, necessitating changes to working practices and sometimes to organisational structure.

In essence, CRM provides management with the opportunity to implement relationship marketing on a company-wide basis. However, for CRM to be successful, all of these activities need to be managed in combination. What makes this possible are the recent advances in enterprise software. One company pioneering these developments, Sun Microsystems, identifies three levels of customer information technology. At the simplest level are reporting tools that link sales staff with other elements of the business. Then there is online analytical programming (OLAP) which analyses data as it comes in, enabling users to 'drill down' through levels of data to examine exceptions to purchase patterns and to understand trends and anomalies. The third level, data mining, is more sophisticated still, and enables obscure correlations to be identified. It might, for example, reveal that sales of baby food increase if it is placed near to the beer shelves in a supermarket! (Sunday Times, 1999). 


\section{The Adoption of CRM by Industry Sectors}

Despite the enthusiasm of many commentators, acceptance of CRM is by no means universal. Woods and Remondi (1996) found that many high-technology companies do not recognise the potential benefits of CRM to sales effectiveness and long-term marketing success and still use traditional marketing approaches. Others think that these classical marketing skills, and the basics of quality, cost and convenience, rather than "expensive IT and neural networks", are what is really needed to give an organisation a competitive edge (Hagel, Bergsma, \& Dheer, 1996). Certainly there is anecdotal evidence that the finance sector is trying to run before it can walk when it implements advanced IT/marketing practices before absorbing the basic underlying tenet of customer orientation. A report by the Consumers' Association concluded that, far from rewarding customers for loyalty, banks often leave them out of pocket (Consumers' Association, 1999). Criticisms of this sort led the government to commission the Cruickshank Banking Report which estimated that the major UK banks overcharge their customers by between $£ 3$ and $£ 5$ billion per year. Payments, though efficiently automated, still take just as long to make as they did in Victorian times. Consequently, banking services to small businesses are to be referred to the Competition Commission (The Times, 2000).

Even without such pressure from government, the need for change in the financial sector is already being driven by economic need and competition. The Cruikshank Report acknowledges that there is no need for action in the individual banking sector where banks are experiencing strong competition from new market entrants who can offer better customer service without the banks' legacy of perceived inefficiency, poor service, and mis-selling (Mitchell, 1997; Ratcliff, 1998).

In other industry sectors hard evidence of an increasing focus on customer profitability, lifetime value, retention and satisfaction, is reported by Abram Hawkes and Market Shape. They found that $90 \%$ of organisations recognise the value of customer retention: $60 \%$ thought that there were links between customer loyalty and the duration of the customer relationship, and $45 \%$ said that loyalty marketing yielded a better return on investment than expenditure on advertising (Reed, 1997). Successful companies manage customer relationships based on potential profitability (Economist 
Intelligence Unit, 1998).

There is growing recognition in the literature that companies will have to adapt to survive, and that this means fundamental changes in the way that firms are organised (for example Webster, 1992; McDonald et al., 2001). A key challenge facing firms in making this transition is the efficient integration of CRM initiatives into wholecompany customer relationship development.

\section{Committing to CRM: Organisational Issues}

A major change is already underway. The proportion of firms organised around their customers is expected to rise from the current level of about $20 \%$ to $50 \%$ by 2002 . By that time, about three-quarters of firms expect to achieve a high degree of integration between sales and IT functions in contrast to less than 30\% in 1998. To support these changes, the proportion of companies operating a data warehouse is expected to more than double to over $80 \%$ (The Economist Intelligence Unit, 1998).

Management academics have been preaching customer orientation for decades, but practice has remained stolidly product orientated (see e.g. Levitt, 1960 \& 1986; Drucker, 1973). However, a combination of factors has now simultaneously obliged and enabled firms to re-organise around their customers; widespread changes in business processes, growth of the services sector, and the availability of cost-effective software solutions to the challenges of 'mass-customisation'. Although these factors are facilitating the shift from product management to a customer focus, the shift will not be easily achieved. The necessary changes will impact on the ways that companies view their customers and how they treat them, how they are themselves organised and how they measure and reward success.

As companies attempt to re-orientate themselves around customers, individual employees will have to come to terms with changing cultural norms, organisational structures and the way that their performance is measured and rewarded. Studies by Martiny (1998) and Braganza \& Myers (1996) indicate that the commitment of senior management is critical to success. This was reinforced in a META Group report 
(1998) that singled out the Chief Executive Officer's (CEO) involvement as a key success factor for CRM projects, concluding that, "Investing in CRM technology without a customer-oriented cultural mindset - inherited hierarchically throughout the enterprise from the CEO - is like throwing money into a black hole”.

Data management systems are the tools that enable the whole firm to reorganise around its customers, but they are not sufficient in themselves. Companies that regard customer information management as a marketing department responsibility and leave it in the hands of marketing planners and product managers in the expectation of short term payoffs are missing the point. The adoption of customer-oriented strategies requires an organisational culture that is adaptive and responsive to change, and the quality of communication within an organisation is an important aspect of any change initiative. Failure to successfully communicate a change initiative and its implications for employees can lead to failure; an effective internal communication strategy needs to be in place, so that there is 'buy-in' to the initiative led by the top-management team. However, if cultural change is to take place, then the way that success is measured and rewarded must change first (Jennings, 1997).

\section{CRM Adoption and Management Metrics}

Spitler (1997) reinforces Jenning's view, pointing out the failure of many industries to adopt appropriate metrics, "If there is a single shortfall today in the [banking] industry's migration to a customer relationship model of the business, it is the lack of adequate, insightful customer MIS (Marketing Information Systems) and customer performance metrics." Many commentators are also concerned about the shortcomings of existing performance measurements, such as Return on Investment (ROI) which:

- Does not incorporate off-balance sheet items, especially the intangible assets that increasingly influence business performance.

- Does not encourage management to invest in assets that do not influence shortterm performance, and so does not strategically position the organisation for the future.

- Is subject to accounting manipulation and other factors that distort the reported performance of the firm. 
Kaplan \& Norton's (1992) Balanced Score Card approach was the first significant attempt to provide metrics across the enterprise. This was followed by Edvinsson, who founded the Intellectual Capital movement which stresses the importance of metrics to address, "the possession of knowledge, applied experience, organisational technology, customer relationships and professional skills that provide knowledgebased companies with a competitive edge in the market place" (Edvinsson \& Malone, 1997). It is the quality of an organisation's customer information and its ability to manage customer relationships that are going to be the critical measures of long term success. Technology, process, organisation and customer orientation are all vitally important to this, but it is the individual employees who are the building blocks of customer relationships. Therefore, the measurement system should facilitate and reward customer orientation. Meeting the organisational challenges of customer orientation, marketing and technology skills will become increasingly more important for employees. Constant training to reinforce existing procedures and to implement newly created programmes is needed to maintain a competitive edge (McDonald, 1993).

Examples of good practice include Dell Computer Corporation, whose technicians are trained to hone the customer relation skills they need for telephone support and problem guidance, and to focus directly on the customer's needs without using technical jargon. The Ritz-Carlton hotel group combines employee training with information systems to provide its guests with superior service, whenever they stay with the hotel chain. Employees are given a 'guest preference pad' to record every preference gleaned from conversation, or observation. These are entered daily onto a world-wide database so that the requirements of a guest staying at any other RitzCarlton in the world are immediately known to the staff. In both cases, staff training and motivation are vital; a great deal depends upon accurate and consistent recording of information and the ability of staff to multi-task across functional boundaries (Ryals, Knox and Maklan, 2000).

\section{CRM Convergence and Cross-functional Integration.}


The key principles involved in relationship marketing are the gathering, co-ordinating and analysing of accurate data on customers, developing marketing strategies that personalise the relationship, and maximising the value to the organisation by focussing on higher value customers. This calls for a considerable degree of crossfunctional co-operation. For example, all of the departments that have dealings with customers (e.g. accounts, despatch, sales, customer service and even distributors and agents) normally hold data on them. Organising the whole firm around its customers requires the convergence of these disparate information systems in order to accelerate processes and facilitate "whole customer" information sharing. This is a key CRM role, "CRM integrates marketing, sales and service functions through business process automation, technology solutions and information resources to maximise each customer contact. CRM facilitates relationships among enterprises, their customers, business suppliers and employees." (Galbreath, 1998). This convergence of business functions assists in cost reduction, efficiency improvements and increased productivity (Elliott, 1997) and should pervade the culture of the organisation.

However, Hall (1997) found that, even where organisations have technological integration, performance integration does not always follow. Many departments and individuals see customer handling as a sales or marketing function, and regard the release of their data to another function as signalling a loss of power. Software developers are becoming increasingly aware of these problems. By learning from implementation difficulties in early Enterprise Resource Planning (ERP) systems, the new wave of post-ERP systems will address, “...the cultural and organisational shifts needed to align IT and business-management objectives once and for all." (Stein and Caldwell, 1998).

While the role of key account manager plays an important part in customer relationships, functional boundaries can limit managers' ability to fulfil the key account role effectively. Therefore, in order to neutralise the negative impact which functional boundaries can have on the successful implementation of CRM, an integrated approach is required, with marketing, operations, information technology, and financial accounting all participating (Morris, 1994). Although the ultimate goal of integration may be the segment-of-one, where product / service offers are tailored 
specifically to the individual, but is not yet achievable in most companies. Even realigning to serve a 'segment-of-several' requires far greater cohesion between business units than currently exists (Larson, 1996).

Hall (1997) notes that the critical interface is between marketing and CRM technology. An understanding of the perspective from both of these disciplines is a prerequisite of cross-functional integration:

\section{The Marketing Perspective}

The marketing perspective on CRM hinges on its potential to offer better customer service, and to improve marketing effectiveness through better focus (McDonald and Wilson, 1999; Bessen, 1993). IT can help improve customer service in a number of areas, including reliability, efficiency, and communications as well as quality control and service monitoring (Berkley and Gupta, 1994)

CRM systems offer operational improvements (Stein and Caldwell, 1998), the opportunity to capture and analyse information about purchasing behaviour - often in real time (Hagel and Sacconaghi, 1996) and long-term success through deeper and closer customer relationships (Beckett-Camarata, Camarata, \& Barker, 1998). Detailed customer profiles facilitate precise matching of marketing offers to prospects (Harrison, 1993), and can be used to track the effectiveness of marketing programmes (Mann, 1990), as well as providing the basis for future planning (Shani and Chalasani, 1993). Customers also benefit when product / service offers are tailored to them individually or in micro-segments and can lead to greater loyalty (Mitchell, 1998). According to Schulz (1996), the combination of customer demands and new enabling technologies make the move to one-to-one marketing inevitable.

Conversely, customer data analysis and profiling also enables an organisation to identify the customers it does not want to serve. The Pareto rule suggests that $80 \%$ of profits are generated by $20 \%$ of customers, but in some industries even more extreme differences in customer profitability exist, "Some commercial banks have found that $10 \%$ of their current account customers are responsible for more than $100 \%$ of their 
profits (i.e. the other $90 \%$ are, on average, loss-making)" (Stone, McFarlane, Visram and Kimmel, 1996).

Although developments in CRM have often been short-term and uncoordinated in the past, recognition of the need for cross-functional, IT integration is now so strong among marketing practitioners that integration of the sales system with other business processes is the highest priority for sales and marketing investment (McDonald and Wilson, 1999; Ferguson and Shaw, 1996). However, despite this, a very recent survey by Simpson Carpenter Research of 100 global companies reveals that CRM budgets still seem to be allocated across business functions on a rather piecemeal basis, with less than $25 \%$ of firms holding a central, enterprise budget (Internet Business, 2001). IT departments were found to be the main custodians of CRM budgeting (see Figure $3)$.

Figure 3: CRM budget holders

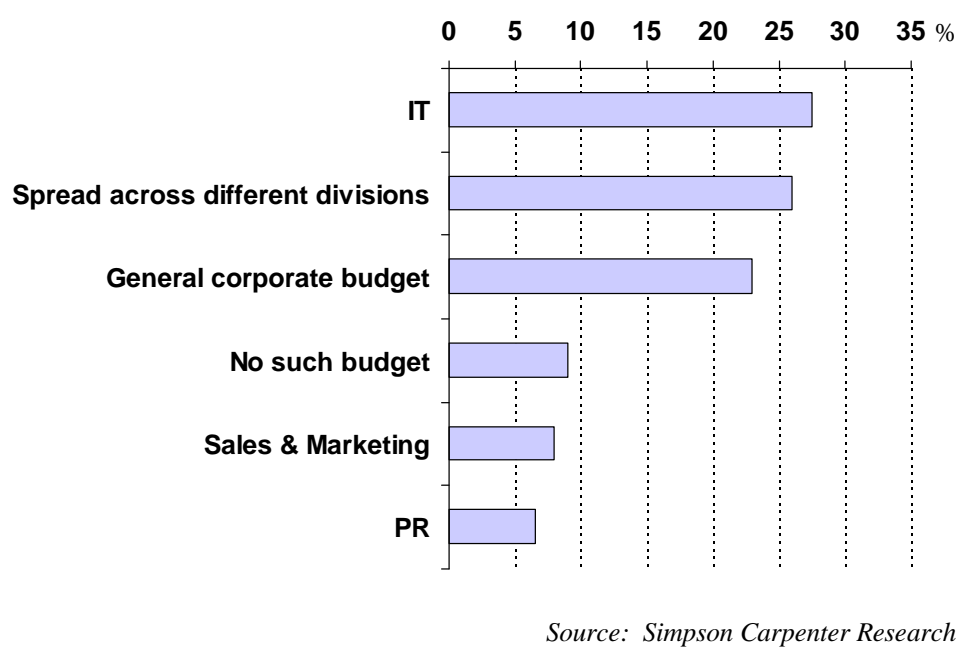

The IT perspective

According to Schultz (1993), the IT perspective is that changes in CRM practice are being driven both by evolving customer demand and by developments in the enabling technologies. Despite this, IT managers do not always see customer development as part of their business challenge, and some are reluctant to share customer data with other departments because such information is their power-base. It is often crossfunctional integration problems like this, rather than technological problems, that are 
the major impairment to progress (Domegan, 1996; Stone, McFarlane, Visram and Kimmel, 1993; Elliott, 1997).

Some of the responsibility for this lack of cross-functional integration lies with senior managers who fail to recognise the importance of the technological underpinning for CRM. According to Hewson (1999), board level support for major IT projects is rare - though very helpful when it happens. Rees-Mogg (1997) attributes this, in part, to board members' superficial understanding of IT combined with their inability to decide what they need. This in turn contributes directly to the difficulties that IT managers experience in scoping out CRM projects where the organisational goalposts seem to move continuously. Board directors, for their part, can feel that investment in IT projects is often much higher, and the benefits much lower, than promised.

Criticisms such as this have led to pressure on IT managers. Grindley (1995) notes that there is still no general acceptance at board level of the need for large scale spending on IT infrastructure and often financial benefits are attached to IT projects that are not expected from other parts of the company.

For their part, IT managers sometimes feel that they have a better vision for the business than line directors (Hewson, 1999). Their challenge is selling their vision to the board. According to Grindley (1995), IT managers have even been known to upwardly adjust the numbers for return on investment in order to push through the changes they believe are fundamental to the long-term success of the business, disguised as short-term efficiency gains (McDonald and Wilson, 1999).

A major concern for IT practitioners contemplating a major investment in CRM technology is the high failure rate of IT projects. In a series of studies cited by Leverick, Littler, Bruce and Wilson (1998) they quote from a survey of 400 British and Irish companies which found that only $11 \%$ of respondents claimed their installation had been successful. In another, it is claimed that between $30-40 \%$ of IT projects realised no appreciable benefits at all. A third study found that three-quarters of IT projects were either uncompleted or not used when they were completed. However, from the IT manager's perspective, the main problem is more about 
management rather than IT failures. These management issues include: absence of strong sponsorship, a lack of cultural readiness, inadequate supporting budgets and an absence of complementary customer management skills (Stone, Woodcock, Foss et al, 1998). The British Computer Society's Technical Board agrees that many project failures are due to business needs not being adequately translated into IT strategy. Consequently, the Society has recently approved the formation of a new Specialist Group for people working as the interface between IT and business users. The aim of this Group is to transform the relationship between business and IT departments and define a new career path for IT people who they say are currently struggling with little or no recognition. This is very much to the profession's credit, but the view from the other side of the business interface is less encouraging: a recent survey endorsed by the Institute of Directors showed that about half of UK directors had never been briefed on their company's technology - and never intend to have such a briefing (Kavanagh, 2000).

\section{Managerial Implications}

IT has the potential to transform relationship marketing by generating market knowledge, supporting group decision-making, and facilitating customer transactions (Business Intelligence 1994). The financial services industry has taken an early lead in CRM implementation (Codington and Wilson, 1994) because its transactions are essentially IT-based, and these firms already hold a wealth of information about individual customers. However, the use of technology on its own is not sufficient. Although most financial services companies now have at least some form of customer marketing database, they do not always perform well in supporting customer development (Naval, 1998; Anon, 1993). Developments in IT must be combined with a relationship marketing philosophy that calls for the re-organisation of the firm around its customers. Re-organisation of the firm around its customers has some immediate implications for managers:

- A culture change that recognises that customers, not just products, drive profits. Marketing actions must, therefore, focus on long-term customer relationships, not just the short-term campaigns. 
- A change in business measurement and incentives so that they reflect this new culture. For marketing, this might mean setting targets for customer retention as well as for new customer acquisition; for IT, this might mean measuring the success of a CRM technology project in terms of its contribution to building relationships with customers rather than its architecture and functionality.

- A change in working practices so that information is shared between departments to build up a picture of the firm's total relationship with the customer. This may also entail a change in organisational structure from traditional functional silos to cross-functional teams.

Two technology issues are critical: a strategic view of investment in properly managed IT, and an enterprise-wide approach to the use and integration of IT systems (McDonald and Wilson, 1999; Haapaniemi, 1996; Tavinen, 1995). The importance of technology in CRM implementation is such that these issues of strategic investment in IT and integrated IT systems may have to be addressed directly through:

- A clearer view about the business case for CRM investments which needs to be built around the longer-term impact of such investments on the firm's relationship with its customers, and not the short-term tactical benefits.

- Acceptance that CRM technology investments should be an enterprise-wide decision, heralding an end to small-scale projects that fail when their success in one business unit leads to ill-judged and hurried attempts to scale them across the organisation, often against the better judgement of the IT managers.

- Board support for the decision to invest in CRM, with board-level representation for the project. Top management buy-in must be seen to be taking place.

- Commitment to providing customer information to the 'front line' of staff who interface with customers, and breaking down the barriers of ownership associated with customer information.

In summary, successful implementation of CRM will require more effective management of functional interdependencies through process teams (Parson, Zeisser 
and Waitman, 1996), and revisions in the ways that employee performance is measured and rewarded. Such a radical shift in expectations and behaviour towards CRM can only be achieved with the full commitment and support of the board and senior management (Fletcher and Wright, 1996; Perrien, Filiatrault and Ricard, 1993).

\section{References}

Anton, J. (1996) Customer relationship management: making hard decisions with soft numbers, Prentice-Hall, New Jersey.

Anonymous, (1993) Customer service makes conflicting demands on IT, Insurance Systems Bulletin, 9 (4), pp 6-7.

Beckett-Camarata, E.J., Camarata, M.R., and Barker, R.T. (1998) Integrating internal and external customer relationships through relationship management: A strategic response to a changing global environment, Journal of Business Research, 41 (1), pp 71-81.

Berkley, B.J. and Gutpa, A. (1994) Improving service quality with information technology, International Journal of Information Management, 14 (2), pp 109-121.

Berry, L.L. (1983) Relationship marketing . In L.L. Berry, G.L. Shostack and G.D. Upah (eds), Perspectives in Services Marketing, American Marketing Association, Chicago Ill.

Bessen, J. (1993) Riding the marketing information wave, Harvard Business Review, 71 (5), pp150-160.

Braganza, A. and Myers, A. (1996) Issues and dilemmas facing organisations in the effective implementation of BPR, Business Change and Re-engineering, 3(2).

Christopher, M., Payne, A. and Ballantyne, D. (1991) Relationship Marketing, Butterworth-Heinemann, Oxford.

Codington, S. and Wilson, T. (1994) Information systems in the UK insurance industry, International Journal of Information Management, 14 (3), pp 188-203.

The Consumers' Association (1999), Which?, September, Hertford.

Couldwell, C. (1998) A data day battle, Computing, May 21, pp 64-66.

Deighton, J. (1998) The future of interactive marketing, Harvard Business Review Vol. 74 (6) pp 151-160. 
Domegan C.T. (1996) The adoption of information technology in customer service. European Journal of Marketing, June. Vol. 30 (6) pp 52-69.

Drucker, P. (1973) Management: tasks, responsibilities, practices, New York, Harper and Row.

Economist Intelligence Unit (1998) Managing customer relationships, The Economist Intelligence Unit, Report with Andersen Consulting.

Edvinsson, L. and Malone, M. (1997) Intellectual capital: redefining your company's true value by finding hidden brainpower, New York, Harper Collins Publishers.

Elliott, C., (1997) Everything wired must converge, Journal of Business Strategy, 18 (6), pp 30-34.

Ferguson, N. and Shaw, A. (1996) Alone and unloved, Conspectus, November.

Fletcher, K. and Wright G. (1996) The strategic context for information systems use; an empirical study of the financial services industry. International Journal of Information Management, 16 (2) pp 119-131.

Ford, D. (1990), Understanding Business Markets, London, Academic Press.

Galbreath, J. (1998) Relationship management environments, Credit World, 87 (2), pp 14-21.

Griffith, V. (1997) Freedom fantasy: an interview with Stephen Roach, Financial Times, 13 August.

Grindley, K. (1995) Managing IT at board level, $2^{\text {nd }}$ edition, FT Pitman, London.

Haapaniemi, P. (1996) Cyber-strategy, Journal of Business Strategy, 17(1), pp 22-26.

Hagel, J. and Sacconaghi, A.M. (1996) Who will benefit from virtual information?, The McKinsey Quarterly, 3, pp 22-37.

Hagel, J., Bergsma, E.E. and Dheer, S. (1996) Placing your bets on electronic networks, The McKinsey Quarterly, 2, pp 56-67.

Hall, D. (1997) Computerisation - where's the return on investment, Management Accounting, 75 (6), pp 40-41.

Hamel, G. and Prahalad, G.K. (1994) Competing for the future, Boston, Mass., Harvard Business School Press.

Hammer, M. and Champy, J. (1993) Reengineering the corporation, New York, Harper Business. 
Harrison, J.J. (1993) Transforming data into relationships. National Underwriter Life and Health - Financial Services Edition, 3 August, N31 pp 7-8.

Hewson, N. (1999) Quoted in MacDonald and Wilson (1999), op cit.

Internet Business, (2001), April, p 25.

Jennings, A. (1997) Customer relationship management using customer scoring, Credit Management, November, pp 30-32.

Kaplan, R. S. and Norton, D. P. (1992) The Balanced scorecard: measures that drive performance, Harvard Business Review, January- February, pp 71-79.

Kavanagh , J. (2000) Time to bridge the gap, The Times, $16^{\text {th }}$ February.

Kutner, S. and Cripps, J. (1997) Managing the customer portfolio of healthcare enterprises, The Healthcare Forum Journal, 40 (5), pp 52-54.

Landberg, S. M., (1998) Taking advantage of convergence, National Underwriter (Property \& Casualty/Risk \& Benefits Management), 102 (39), pp 59-61.

Larson, M. (1996) In pursuit of a lasting relationship, Journal of Business Strategy, 17 (6), pp 31-33.

Leverick, F., Littler, D., Bruce, M. and Wilson, D. (1998) Using information technology effectively: a study of marketing installations, Journal of Marketing Management, 14 (8), pp 927-962.

Levitt, T. (1960) Marketing myopia, Harvard Business Review, July-August, pp 4556.

Levitt, T. (1986) The marketing imagination, New York, Free Press.

Lockard, M. (1998) Test your retention IQ, Target Marketing, 21 (3), pp 32-41.

Lusch, R. \& Harvey M. (1994) The case for an off-balance controller, Sloan Management Review 35, pp 101-105.

Mann, D.C. (1990) Database marketing, how it's changing your business, Bank Marketing, 22 (8), pp 30-34.

Martiny, M. (1998) Knowledge management at HP consulting, Organizational Dynamics, 27 (2), pp 71-77.

McDonald, L. (1993) Setting new standards for customer advocacy, Journal of Business Strategy, 14 (1), pp 11-15.

McDonald, M.H.B. and Wilson H. (1999) e-marketing: improving marketing effectiveness in a digital world, London, Financial Times Prentice Hall. 
McDonald, M.H.B, Christopher M, Knox S D and Payne A (2001), Creating a Company for Customers: How to build and lead a market-driven organization, Financial Times Prentice Hall Publishing, London and Brazil.

META Group (1998) The seven deadly sins of CRM implementation, META Group Report, November 1998.

Mitchell, A. (1998) Why intimacy is vital to customer relationships, Marketing Week, 21 (37), pp 30-31.

Mitchell, A. (1997) Swimming with the Sharks, Marketing Business, September.

Morris, T. (1994) Customer relationship management: CMA Magazine, 68 (7), pp $22-$ 25 .

Naval, M. (1998) Businesses missing the info advantage, Computing Canada, 24 (20), pp 13-15.

Parsons, A.J., Zeisser, M. and Waitman, R. (1996) Organising for Digital Marketing, McKinsey Quarterly, No.4, pp 185-192.

Peppers, D. and Rogers, M. (1995) A new marketing paradigm, Planning Review, 23 (2), pp 14-18

Perrien, J., Filiatrault, P. and Ricard, L. (1993) The implementation of relationship marketing in commercial banking, Industrial Marketing Management, 22 (2), pp 141148.

Ratcliff, P. (1998) Is that a bank in your pocket, Banker, 148 (873), pp 86-87.

Reed, D. (1997) Held to account, Marketing Business, pp 45-50.

Rees-Mogg, W. (1997) Is Bill Gates really selling us all Ladas?, The Times, 15 December, p 20.

Reeves, B. (1998) Make new friends but keep the gold, Wireless Review, 15 (8), pp 28-32.

Reichheld, F.F. (1996) The Loyalty Effect, Boston, Mass, Harvard Business School Press.

Reicheld, F.F. and Sasser, W.E. jnr, (1990) Zero defections: quality comes to services, Harvard Business Review, September-October, pp 105-111.

Ryals, L., Knox, S.D. and Maklan, S. (2000) "Customer Relationship Management (CRM): Building the Business Case", F.T. Management Research in Practice Series, London. 
Schultz, D.E. (1993) Marketing from the outside in, Journal of Business Strategy, 14 (4), pp 25-29.

Schultz, D.E. (1996) The inevitability of integrated communications, Journal of Business Research, 37 (3), pp 139-146.

Shani, D. and Chalasani, S., (1993) Exploiting niches using relationship marketing, Journal of Business \& Industrial Marketing, 8 (4), pp 58-66.

Spitler, R. (1997) Relationship management: the new paradigm, The Journal of Lending \& Credit Risk Management, 79 (11), pp 51-56.

Stein, T. and Caldwell, B. (1998) Beyond ERP - New IT agenda - A second wave of ERP activity promises to increase efficiency and transform ways of doing business, Information Week, November, 30 (1).

Stone, M., McFarlane, P., Visram, F. and Kimmel, C. (1993) Servicing the customer is info tech a bridge or a barrier?, Working Paper, City University, London.

Stone, M, Woodcock, N, Foss, B, et al (1998) Database Marketing and customer recruitment, retention and development: what is the technological state of the art? Journal of Database Marketing, 5 (4), pp 303-331.

The Sunday Times, (1999) 26 September, pp 3-17.

Tavinen, J. M., (1995) Information systems in marketing: identifying opportunities for new applications, European Journal of Marketing, 29 (1), pp 8-26.

The Times, (2000) 21 March, p 25 and p 31.

Woods, T. and Remondi, J. (1996) Relationships vital for high-tech marketers, Marketing News, 20 May.

Webster, F.E. (1992) The changing roll of marketing in the corporation, Journal of Marketing, 56 (4), pp 1-16. 